\title{
UCZONY, NAUCZYCIEL, OBYWATEL
}

\author{
Stanisław Flejterski \\ Wydział Zarządzania i Ekonomiki Usług, Uniwersytet Szczeciński
}

\author{
Profesorowi Franciszkowi Gronowskiemu \\ z okazji niezwykłego Jubileuszu \\ z szacunkiem i sympatią
}

Mój skromny esej ${ }^{1}$, dedykowany Jubilatowi - lubianemu i szanowanemu nie tylko w środowisku szczecińskim - Profesorowi Franciszkowi Gronowskiemu, pragnę zacząć od przypomnienia sławnej kiedyś, interesującej i nadal aktualnej, obejmującej dziewięć grup - typologii naukowców (M. Mazur, Historia naturalna polskiego naukowca, Warszawa 1970). Na czele listy znajdują się naukowcy pionierzy, awanturnicy, ryzykanci, artyści, którzy stojąc na leśnej polanie dręczą się pytaniem - „ale co jest w tym lesie?” Łamią uznane prawa i teorie naukowe, tworząc nowe. Oni też bywają autorami zaskakujących pomysłów wynalazczych. Tuż za nimi można wymienić naukowców klasyków, mistrzów rzemiosła naukowego, kapłanów strzegących ładu w nauce, którzy nie wyjdą poza obręb owej leśnej polany, ale postarają się wszystko na niej wykryć w ramach istniejących praw. Klasycy, niecierpiący pionierów jako burzycieli umiłowanego ładu, skorzy są do nazywania ich ,pseudouczonymi”, do czego zresztą pionierzy dają im nierzadko powody. Pionierzy odwzajemniają się im epitetem „wrogów postępu w nauce”, w czym także miewają słuszność. Pomimo tego antagonizmu, a może raczej dzięki niemu, na tych dwóch grupach naukowców stoi rozwój nauki. Bez pionierów groziłaby nauce stagnacja, bez klasyków - nauka mogłaby zejść na manowce i stać się szarlataństwem. Gdy pionierskie idee w konflikcie z kanonami rzemiosła naukowego wychodzą zwycięsko, wówczas jako nowe prawdy zostają włączone do skarbca wiedzy. Trzecie miejsce - zdaniem M. Mazura - należałoby przyznać naukowcom stymulatorom, naukowcom postulatorom, naukowcom reżyserom, którzy sami nie podejmują rozwiązywania problemów, ale są obdarzeni zdolnością ich

1 Esej (fr. essai- „próba”) - forma literacka lub literacko-naukowa, prezentująca autorski punkt widzenia .Badacze mają problem z określeniem, czym tak naprawdę jest esej, w tym esej naukowy,, uważa się nawet, że jego zdefiniowanie jest niemożliwe. Za twórców eseju uznaje się Michela de Montaigne’a, renesansowego humanistę, który napisał dzieło Essais (Próby z 1580 r.) i Francisa Bacona, odrodzeniowego filozofa, autora Essays or Counsels, civill and moral. W rzeczywistości eseje powstawały już w czasach starożytnych (Plutarch, Platon, Seneka Młodszy, Marek Aureliusz ,Cyceron ). Zwane były wówczas „szkicami” i posiadały formę luźnych przemyśleń, zazwyczaj o charakterze filozoficznym. 
wynajdywania, stawiania i podsuwania innym, a jak wiadomo, właściwe postawienie problemu to już część jego rozwiązania. Ci nie wyjdą z polany do lasu, ale mogą pokazać, czego brakuje na samej polanie. Mogą pomóc w rozwiązaniu problemu przez wskazanie repertuaru metod i źródeł informacji. Tego rodzaju naukowcy, których można by też nazwać metodologami, są przydatni do organizowania, koordynowania i przewodniczenia w zespołowej pracy naukowej. Jako czwartą grupę można wymienić naukowców erudytów, kompilatorów, krytyków, mających upodobanie w gromadzeniu, konfrontowaniu i przetrawianiu cudzych idei, aby je potem podać w sposób usystematyzowany i krytycznie oceniony. Są oni zwykle autorami wartościowych monografii naukowych, a ich umiejętności są szczególnie cenne w kształceniu młodych naukowców.

Do której z tych czterech grup naukowców można zaliczyć Jubilata? Wydaje się, że Profesor Franciszek Gronowski jest naukowcem „z pogranicza”, zasługuje, aby być zaliczonym - w różnej mierze - do każdej z wymienionych kategorii. Dodajmy, że granice między tymi kategoriami są płynne. Profesor Gronowski był przez kilkadziesiąt lat kariery akademickiej pionierem, klasykiem, stymulatorem, erudytą... Podstawą do takiej subiektywnej konstatacji (i wcale nie jest to jubileuszowa kurtuazja!) jest moja wieloletnia znajomość Jubilata, datująca się od przełomu lat sześćdziesiątych i siedemdziesiątych minionego stulecia. Chociaż nie było mi dane być studentem Profesora Gronowskiego, to przecież miałem wiele razy okazję czytać Jego teksty naukowe, popularno-naukowe i publicystyczne (ze sławnymi felietonami włącznie), słuchać Jego wykładów, wypowiedzi podczas konferencji, posiedzeń rad wydziału, spotkań towarzyskich... Profesjonalizm, wybitne kompetencje merytoryczne w dziedzinie gospodarki morskiej, pasja, elokwencja, last but not least - legendarne poczucie humoru...

Barwna osobowość, dorobek naukowy, wieloletnie związki z praktyką, najwyższe funkcje pełnione na wydziale i uczelni, osiągnięcia w dziedzinie kształcenia absolwentów, wieloletni wpływ na rozwój kadr naukowych (promotor, recenzent, dyskutant). Roli Profesora Gronowskiego w rozwoju szczecińskiego ośrodka nauk ekonomicznych nie sposób przecenić. Począwszy od końca lat czterdziestych, przez kilkadziesiąt lat był świadkiem i aktywnym uczestnikiem zmian zachodzących w Szczecinie - w nauce, w gospodarce, w polityce, w działalności publicznej (m.in. w ruchu rotariańskim). Bieg dziejów, przemijanie, dramaturgia rozwoju, sukcesy, rozczarowania, nadzieje... Profesor Franciszek Gronowski niejednokrotnie imponował i zapewne nie tylko mnie - mądrością uczonego, nauczyciela i obywatela... Żył w czasach II RP, przeżył PRL, żyje od ponad ćwierćwiecza w wolnej Polsce... Zgromadził wiele bezcennych doświadczeń i interesujących przemyśleń na temat świata, Europy, Polski, rozwoju gospodarki, w tym zwłaszcza gospodarki morskiej, której poświęcił tak wiele lat życia...

Trzymajmy się morza... to przesłanie bez wątpienia bliskie długiemu życiu i pracy Profesora Franciszka Gronowskiego. Warto także przypomnieć, że autorem tych słów był w styczniu 1790 roku Stanisław Staszic: „Przestrogi dla Polski z teraźniejszych politycznych Europy związków i z praw natury wypadające”. Zdumiewające jak aktualnie - po około 227 latach - brzmią ówczesne staszicowskie przestrogi i sformułowane wtedy zalecenia. 